\title{
Myxobolus imparfinis n. sp. (Myxozoa: Myxosporea), a new gill parasite of Imparfinis mirini Haseman (Siluriformes: Heptapteridae) in Brazil
}

\author{
Diego Henrique Mirandola Dias Vieira • Vinícius Panciera Tagliavini • \\ Vanessa Doro Abdallah • Rodney Kozlowiski de Azevedo
}

Received: 31 May 2017 / Accepted: 14 November 2017 / Published online: 1 February 2018

(C) Springer Science+Business Media B.V., part of Springer Nature 2018

\begin{abstract}
A new species of myxozoan, Myxobolus imparfinis $\mathrm{n}$. sp. is described based on material from the gills of Imparfinis mirini (Haseman) (Heptapteridae). Mature myxospores are round, measuring 7.1-8.4 (7.9 \pm 0.3$) \mu \mathrm{m}$ in length, 4.5-6.2 (5.5 \pm 0.5$)$ $\mu \mathrm{m}$ in width and 3.1-4.2 (3.7 \pm 0.3$) \mu \mathrm{m}$ in thickness. The polar capsules are of unequal size, the larger polar capsule measuring 3.4-4.5 (3.9 \pm 0.3$) \mu \mathrm{m}$ in length and 1.4-2.0 (1.7 \pm 0.1$) \mu \mathrm{m}$ in width and the smaller capsule measuring 3.1-3.8 (3.4 \pm 0.2$) \mu \mathrm{m}$ in length and $1.2-1.8(1.5 \pm 0.2) \mu \mathrm{m}$ in width. The polar filament presents 6-7 coils. Spores had a prevalence of infection of $75 \%(6 / 8)$. In histological analyses we detected the development site of spores in primary filaments, in afferent branchial artery, thus classifying the type of infection to the filamental type and vascular
\end{abstract}

This article was registered in the Official Register of Zoological Nomenclature (ZooBank) as BB926388-5A5D-40CF-90BB032F6953AE8D. This article was published as an Online First article on the online publication date shown on this page. The article should be cited by using the doi number. This is the Version of Record.

D. H. M. D. Vieira · V. P. Tagliavini

Departamento de Parasitologia, Universidade Estadual Paulista "Júlio de Mesquita Filho" - UNESP, Botucatu, São Paulo, Brazil

V. D. Abdallah · R. K. de Azevedo ( $₫)$

Departamento de Ciências Ambientais, Universidade do Sagrado Coração (USC), Bauru, São Paulo, Brazil

e-mail: azevedork@gmail.com subtype. The phylogenetic analyses of a dataset including species Myxobolus Bütschli, 1882 and Henneguya Thélohan, 1892 from South America recovered $M$. imparfinis n. sp. as a sister species of Myxobolus flavus Carriero, Adriano, Silva, Ceccarelli \& Maia, 2013. To our knowledge, this is the first record of a myxozoan species parasitising I. mirini.

\section{Introduction}

Myxozoans are parasites of the phylum Cnidaria Hatschek, 1888 that can be pointed out as some of the main causative agents of fish injuries. The most diverse genus within the Class Myxosporea Buetchli, 1881 is Myxobolus Bütschli, 1882 comprising species which parasitise mainly fishes (Eiras et al., 2014). The importance of the study of myxozoans was evidenced by Barassa et al. (2003), who showed that some species can cause serious problems to their hosts, resulting in high mortality rates.

Fishes belonging to the order Siluriformes (Nelson) are perhaps the most well represented in South America, with about 1,056 species described (Buckup et al., 2007). Imparfinis mirini (Haseman), belongs to the family Heptapteridae (Gill), a large, diversified and well-distributed fish group in the Neotropical region (Ferraris, 2007).

The use of molecular data in conjunction with morphological analysis has been used to describe new species of myxozoans (e.g. Carriero et al., 2013; 
Capodifoglio et al., 2016). The main goal of this study was to describe a new species of Myxobolus, found in the gills of I. mirini during a parasitological survey, based on light microscopy, histology and assessment of its phylogenetic relationships with other representatives of the family Myxobolidae Thélohan, 1892 from South America.

\section{Materials and methods}

In August 2016, specimens of I. mirini ( $\mathrm{n}=8$; total length of $6.2-7.0 \mathrm{~cm}$, weight of $1.98-2.4 \mathrm{~g}$; 6 females/ 2 males), were collected in River Batalha $\left(22^{\circ} 29^{\prime} 04.6^{\prime \prime} \mathrm{S}, 49^{\circ} 03^{\prime} 53.3^{\prime \prime} \mathrm{W}\right)$, Agudos, São Paulo, Brazil. Fish were collected using sieves and euthanised by neural pithing immediately after capture. Gills, heart, liver, gonad, stomach, intestine, bone marrow, kidney, swim bladder and gall-bladder fresh smears were observed under a differential interference contrast microscope (Leica DMLB 5000, Leica Microsystems, Wetzlar, Germany) at a magnification of $1000 \times$. Gill samples of infected fish were collected and fixed according to the protocols for further morphological and molecular analysis.

Spore length, width and thickness, polar capsule length, width and the number of turns of the polar filament were measured following the recommendations of Lom \& Arthur (1989). Measurements of 30 spores from gills of 6 infected fish were taken from digital images at a magnification of $1000 \times$, under light microscopy with Leica software application suite LAS V3.8 (Leica Microsystems, Wetzlar, Germany). Schematic representation of mature spores was made using the software CorelDRAW ${ }^{\circledR}$ (Corel Draw Graphics Suite, version x8, Corel Corporation, Canada). All measurements are in micrometres and are presented as the range followed by the mean and standard deviation in parentheses.

Infected gills collected for histological analysis were placed into a $5 \%$ formaldehyde, dehydrated in an ethanol series $(3 \times$ into $70 \%$ every $2 \mathrm{~h}$ and then $95 \%$ for $4 \mathrm{~h}$ ). The material was then immersed in a mixture (50\% resin and 50\% ethanol) for $12 \mathrm{~h}$ and embedded in resin (HistoResin, Leica, Wetzlar, Germany). Finally, $3 \mu \mathrm{m}$ sections were made, stained with hematoxylineosin and observed under a light microscope.

Samples of two infected gills were fixed in absolute ethanol for DNA extraction. The DNA extraction followed the animal tissue protocol DNeasy Blood \& Tissue Kit (Qiagen, Hilden, Germany). The SSU rDNA gene was amplified using different primer combinations and PCR conditions (Table 1). Amplifications were performed using a Bio-Rad Mycycler personal thermal cycler (Bio-Rad Laboratories Pty Ltd., Gladesville, Australia), with initial denaturation at $94^{\circ} \mathrm{C}$ for $3 \mathrm{~min}$, followed by $28-34$ cycles of $94^{\circ} \mathrm{C}$ for $40 \mathrm{~s}$, specific annealing temperature for $40 \mathrm{~s}, 72^{\circ} \mathrm{C}$ for $2 \mathrm{~min}$, and a final extension at $72^{\circ} \mathrm{C}$ for $10 \mathrm{~min}$. PCR reactions were performed in $25 \mu \mathrm{l}$ reactions containing $3 \mu \mathrm{l}$ of DNA extract, $1 \mu \mathrm{l}$ of each PCR primer using Ready-to-Go PCR beads (Pure Taq ${ }^{\text {TM- }}$ Ready-to-Go ${ }^{\mathrm{TM}}$ beads, GE Healthcare, Chicago, USA), the solution consisted of stabilizers, BSA, dATP, dCTP, dGTP, dTTP, \pm 2.5 units of puReTaq DNA polymerase and reaction buffer. Each bead was reconstituted to a final volume of $25 \mu \mathrm{l}$ and the concentration of each dNTP was $200 \mu \mathrm{M}$ in $10 \mathrm{mM}$ Tris- $\mathrm{HCl}$ ( $\mathrm{pH} 9.0$ at room temperature), $50 \mathrm{mM} \mathrm{KCl}$ and $1.5 \mathrm{mM} \mathrm{MgCl}_{2}$. After checking for the presence of the expected DNA amplicons in a $1 \%$ agarose gel in TAE buffer, PCR products were cleaned up using QIAquick PCR Purification Kit (Qiagen ${ }^{\circledR}$, CA, USA). Automated sequencing was performed directly on the purified PCR products from specimens using BigDye v.3.1 Terminator Cycle Sequencing Ready Reaction kit (Applied Biosystems, Foster City, CA, USA) for cycle sequencing. Sequences were run on an Applied Biosystems ABI 3500 DNA genetic analyzer, edited in Sequencher $^{\mathrm{TM}}$ v. 5.2.4 (Gene Codes, Ann Arbor, MI) and subjected to BLAST analyses (http://blast.ncbi. nlm.nih.gov).

The newly generated sequences of partial SSU rDNA were aligned using Geneious version 7.1.3 (Kearse et al., 2012) with ClustalW algorithm (Larkin et al., 2007) and default settings with related sequences for species of Myxobolus and Henneguya Thélohan, 1892 from South America retrieved from GenBank. Myxydium ceccarellii Adriano, Silva, Atkinson, Bartholomew \& Maia, 2014 (KJ499821) was used as the outgroup.

All analyses were performed using only positions that were unambiguously alignable across all taxa (621 nt). The JModelTest 2.1.1 program (Posada, 2008) was used to select the most appropriate evolutionary model for Maximum Likelihood (ML) and Bayesian inference (BI) analyses. The best-fitting model of nucleotide substitution was GTR + I + G 
Table 1 Primers used to amplify SSU rDNA in this study

\begin{tabular}{llll}
\hline Primer $^{\mathrm{a}}$ & Sequence $^{\prime}$ - $^{\prime}$ & PCR round & Reference \\
\hline Erib1 & ACCTGGTTGATCCTGCCAG & First & Barta et al. (1997) \\
Erib10 & CTTCCGCAGGTTCACCTACGG & First & Barta et al. (1997) \\
MyxospecF & TTCTGCCCTATCAACTTGTTG & Nested & Fiala (2006) \\
MX5 & CTGCGGACGGCTCAGTAAATCAGT & Nested & Andree et al. (1997) \\
MyxospecR & GGTTCNCDGRGGGMCCAAC & Nested & Fiala (2006) \\
\hline
\end{tabular}

${ }^{\mathrm{a} A m p l i c o n}$ size $c .1,000 \mathrm{nt}$

based on the Akaike Information Criterion (AIC). Node support for ML was determined by performing 1,000 bootstrap replicates.

Bayesian inference (BI) analysis was performed using MrBayes 3.1.2 (Ronquist \& Huelsenbeck, 2003). Markov Chain Monte Carlo (MCMC) chains were run for 10 million generations and the loglikelihood scores plotted. The 'burn in' was set to $25 \%$. Phylogenetic trees were generated and edited in FigTree v1.4 (Rambaut, 2012). An alignment containing only trimmed sequences of Myxobolus spp. parasitising fishes in South America was used to produce a distance matrix.

\section{Family Myxobolidae Thélohan, 1892 Genus Myxobolus Bütschli, 1882}

\section{Myxobolus imparfinis n. sp.}

Type-host: Imparfinis mirini (Haseman) (Siluriformes: Heptapteridae).

Type-locality: River Batalha $\left(22^{\circ} 29^{\prime} 04.6^{\prime \prime} \mathrm{S}\right.$ $\left.49^{\circ} 03^{\prime} 53.3^{\prime \prime} \mathrm{W}\right)$, municipality of Agudos, State of São Paulo, Brazil.

Type-material: Hapantotype (a slide containing fresh spores) was deposited in the Myxozoa Type Slide Collection at the Instituto Nacional de Pesquisa da Amazônia (INPA), Manaus, Brazil under the accession number INPA 31. Histological sections of gills containing spores were also deposited in the collection of the Museum of Zoology "Adão José Cardoso", Institute of Biology, University of Campinas (UNICAMP), São Paulo, Brazil (under the accession number ZUEC-MYX 68).

Site in host: Gills, located in the primary and middle third of the primary gill filaments and developed in the afferent branchial artery.
Prevalence: $75 \%$ (in 6 out of 8 fish examined). Representative DNA sequences: Two SSU rDNA sequences obtained from spores of M. imparfinis $\mathrm{n}$. sp. (1,095 and 1,051 nt; GenBank: MF425815 and MF425816, respectively)

ZooBank registration: To comply with the regulations set out in article 8.5 of the amended 2012 version of the International Code of Zoological Nomenclature (ICZN, 2012), details of the new species have been submitted to ZooBank. The Life Science Identifier (LSID) for Myxobolus imparfinis n. sp. is urn:lsid:zoobank.org:act:17D4A604-104D-48E3-8D8E-0708 610FE639.

Etymology: The specific name (imparfinis) is derived from the genus of the host.

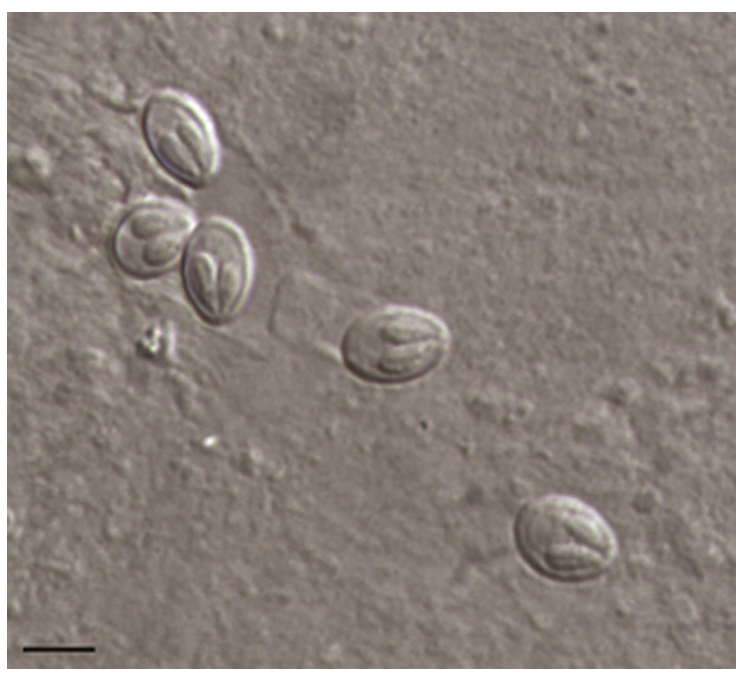

Fig. 1 Light photomicrographs of mature spores of Myxobolus imparfinis $\mathrm{n}$. sp. from the gills of Imparfinis mirini. Scale-bar: 5 $\mu \mathrm{m}$ 


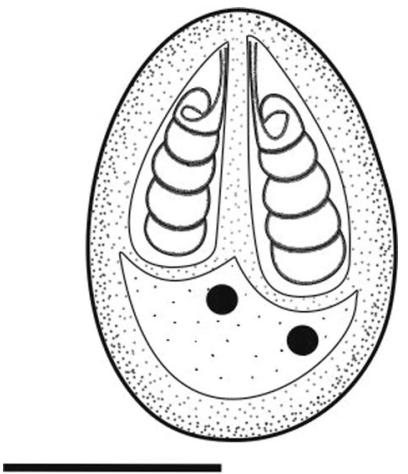

Fig. 2 Schematic representation of a mature spore of Myxobolus imparfinis n. sp. Scale-bar: $3 \mu \mathrm{m}$

\section{Description (Figs. 1, 2, 3, 4)}

Spores[Based on 30 spores.] Spores round, with binucleate sporoplasm. Mature spores from gills 7.1-8.4 (7.9 \pm 0.3$)$ long, 4.5-6.2 (5.5 \pm 0.5$)$ wide 3.1-4.2 (3.7 $\pm 0.3)$ thick. Polar capsules 2 , of unequal size; larger polar capsule 3.4-4.5 (3.9 \pm 0.3$)$ long, 1.4-2.0 (1.7 \pm $0.1)$ wide; smaller pollar capsule 3.1-3.8 (3.4 \pm 0.2$)$ long, 1.2-1.8 (1.5 \pm 0.2$)$ wide. Polar filament with 6-7 coils (Figs. 1-2).

\section{Remarks}

The morphology of the myxospores found in the gills of I. mirini corresponded to the genus Myxobolus following Lom \& Dyková (2006), based on rounded spores containing two polar capsules and a binucleated sporoplasm. The morphology of M. imparfinis n. sp. was compared to other species of Myxobolus that parasite fishes, mainly from South America. The greater focus of comparison concerned Myxobolus spp. that parasitise fishes of the Order Siluriformes (Table 2).

Of the five species (see Table 2 for details), four are parasitic in the gills of their hosts (Myxobolus flavus Carriero, Adriano, Silva, Ceccarelli \& Maia, 2013; Myxobolus niger Mathews, Maia \& Adriano, 2016; Myxobolus sciades Azevedo, Casal, Mendonça, Carvalho, Matos \& Matos, 2010 and Myxobolus cordeiroi Adriano, Arana, Alves, Silva, Ceccareli, HenriqueSilva \& Maia, 2009) and one is parasitic in the opecular cavity of its host (Myxobolus absonus Cellere, Cordeiro \& Adriano, 2002). Myxobolus flavus resembles morphologically $M$. imparfinis n. sp., but all morphometric features are larger than in the new species. Myxobolus niger, M. absonus, M. sciades and $M$. cordeiroi exhibit larger spore length than $M$. imparfinis n. sp. (means $11.3 \pm 0.4 \mu \mathrm{m}, 15.7 \pm 1.5 \mu \mathrm{m}$, $9.15 \pm 0.39 \mu \mathrm{m}$ and $10.8-11.3 \mu \mathrm{m}$, respectively $v s 7.9$ $\pm 0.3 \mu \mathrm{m})$. In addition, only M. absonus has polar capsules of different sizes as in the new species; however both polar capsules are longer than the polar capsules of $M$. imparfinis n. sp. (larger capsule mean $6.4 \pm 0.7 \mu \mathrm{m}$ vs $3.9 \pm 0.3 \mu \mathrm{m}$; smaller capsule mean $4.2 \pm 0.6 \mu \mathrm{m} v s 3.4 \pm 0.2 \mu \mathrm{m})$.

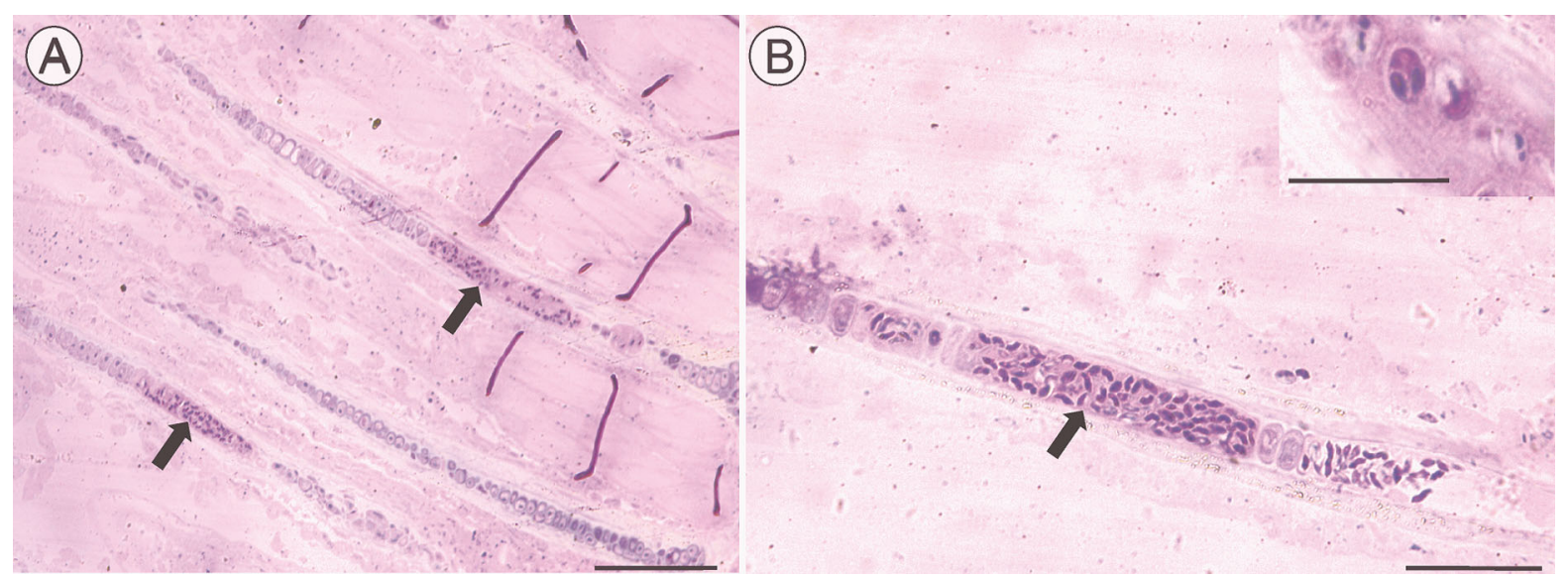

Fig. 3 Photomicrographs of histological sections of gills infected with Myxobolus imparfinis n. sp. A, Histological section of gill filaments from Imparfinis mirini infected with spores of M. imparfinis in the afferent branchial artery (arrows); B, Enlarged image of spores (arrow) developed in afferent branchial artery of a primary gill filament. Inset: detail of spore of M. imparfinis $\mathrm{n}$. sp. Scale-bars: A, $100 \mu \mathrm{m}$; B, $50 \mu \mathrm{m}$ (inset, $20 \mu \mathrm{m}$ ) 


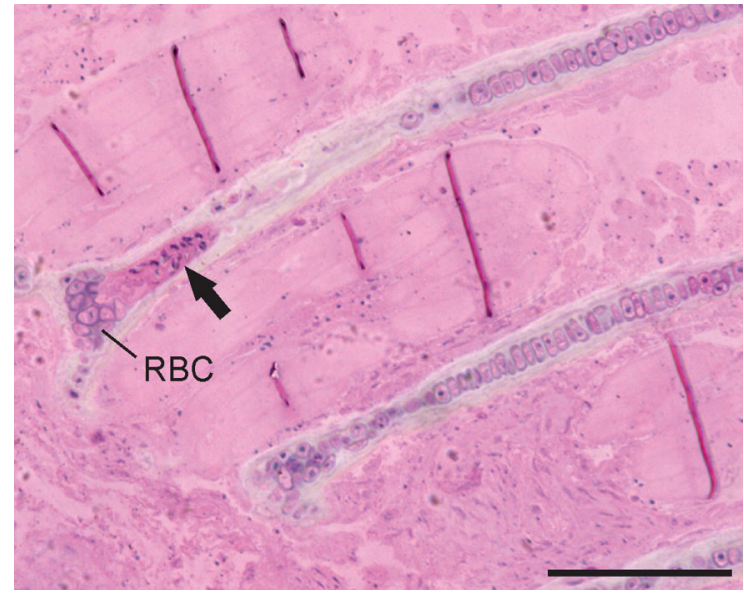

Fig. 4 Photomicrographs of histological sections of gills infected with Myxobolus imparfinis n. sp. showing spores (arrow) located at the beginning of the lumen of the afferent branchial artery blocking the passage of red blood cells (RBC). Scale-bar: $100 \mu \mathrm{m}$

Comparisons were also made with Myxobolus spp. that parasitise fishes of other orders. The species most resembling M. imparfinis n. sp. is Myxobolus brycon Azevedo, Casal, Marques, Silva \& Matos, 2011, but this species has a smaller body width compared with M. imparfinis n. sp.: 3.9-4.8 (4.2 \pm 0.5$) \mu \mathrm{m} v s$ 4.5-6.2 $(5.5 \pm 0.5)$ 4.54-6.17 $\mu \mathrm{m}$. In addition, the polar filament in M. brycon presents 8-9 turns (vs 6-7 turns in M. imparfinis n. sp.) (see Azevedo et al., 2011).

When compared to Myxobolus species from other geographical regions, the species that most closely resembles M. imparfinis n. sp. was Myxobolus omari Székely, Shaharom-Harrison, Cech, Mohamed \& Molnár, 2009. However, M. omari has a body width of $12 \mu \mathrm{m}$, which is much larger when compared with M. imparfinis n. sp. $(5.5 \pm 0.5 \mu \mathrm{m})$ (see Székely et al., 2009). All other species that were compared did not show morphological or morphometric characteristics resembling $M$. imparfinis $n$. sp. Each species verified presented at least one morphometric feature or number of turns of the polar filament significantly different when compared with the new species.

\section{Histological analysis}

The histological analysis of gills of I. mirini revealed that the spores developed in the intralamellar gill regions. The spores were located in the primary and middle third of the primary gill filaments and developed in the afferent branchial artery (Fig. 3A-B). Histological sections also showed the presence of spores at the beginning of the lumen of the afferent branchial artery, blocking the passage of red blood cells of the host (Fig. 4). However, we did not observe any inflammatory influence, secondary infections, mucus production or even deformations of the lamellae in the gills of I. mirini.

\section{Molecular and phylogenetic analysis}

We amplified a fragment of the SSU rDNA gene from spores collected from the gills of two infected I. mirini (1,051 and 1,095 nt long); when aligned the sequences showed a similarity of $99.5 \%$. The BLAST search using the partial SSU rDNA sequence data for $M$. imparfinis $\mathrm{n}$. sp. did not match any myxozoan sequence available on GenBank. The newly generated sequence $(1,095 \mathrm{nt}$ long) was most similar to that for M. flavus (divergence of $12.1 \%$, Table 3).

The generated ML and BI trees showed an identical topology, therefore, only the BI tree is presented here. In these solutions, the South American species of Myxobolus and Henneguya clustered into two clades, one composed only of Myxobolus spp. and the other composed of species of Myxobolus and Henneguya. It was possible to observe the formation of a paraphyletic group formed by the genera Henneguya and Myxobolus. Myxobolus imparfinis n. sp. appeared as a sister species of M. flavus (Fig. 5).

In the clade composed by species of Myxobolus and Henneguya, a clustering by host specificity was observed. The species were divided into two major groups, one composed only of myxozoan parasites of siluriform fishes and the other group composed only of myxozoan parasites of characiform fishes. In the clade composed only of Myxobolus spp., all species are parasites of characiform fishes; however the same pattern of host specificity clustering was observed in relation to the host family. The species were divided into two major groups, one composed only of Myxobolus spp. parasitising fishes of the family Prochilodontidae (Castro \& Vari) and the other group composed only of myxozoan parasites of fishes of the family Bryconidae (Eigenmann). 


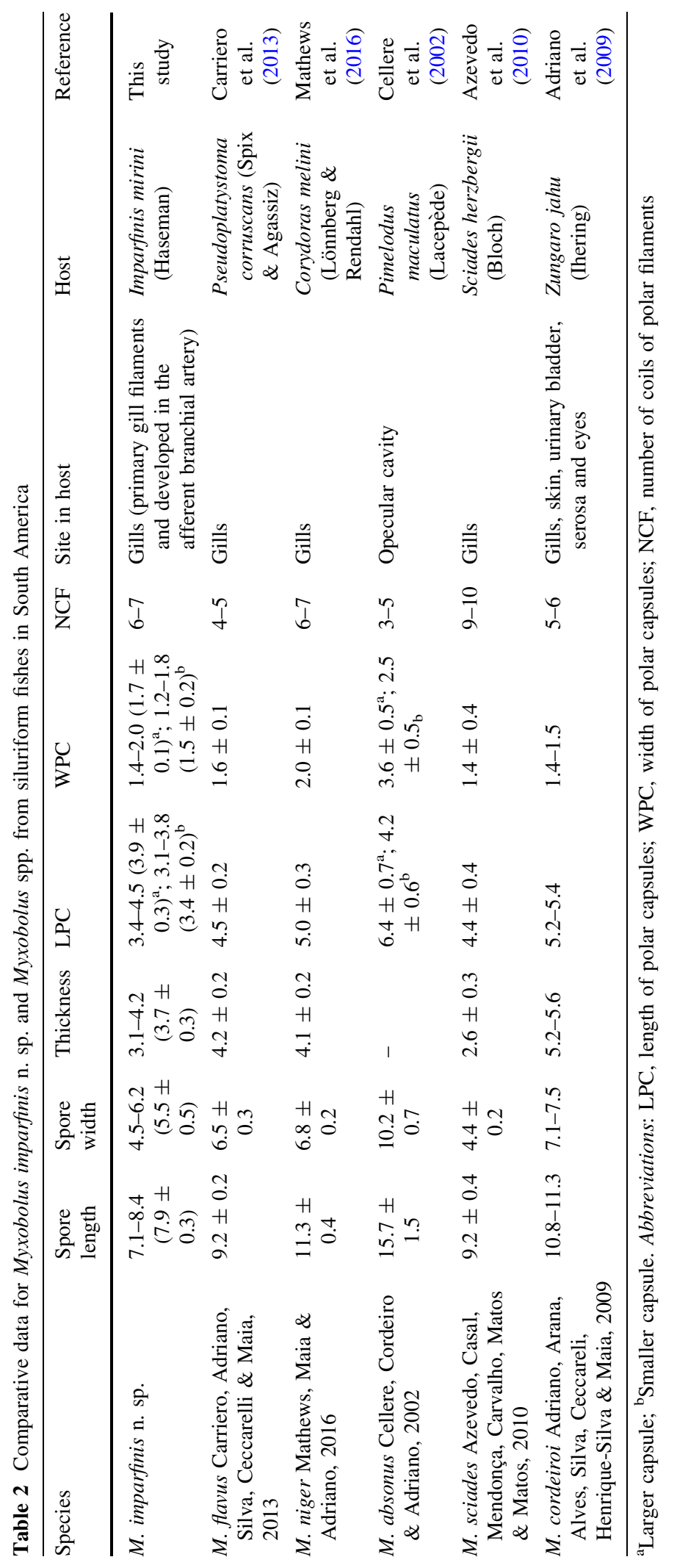




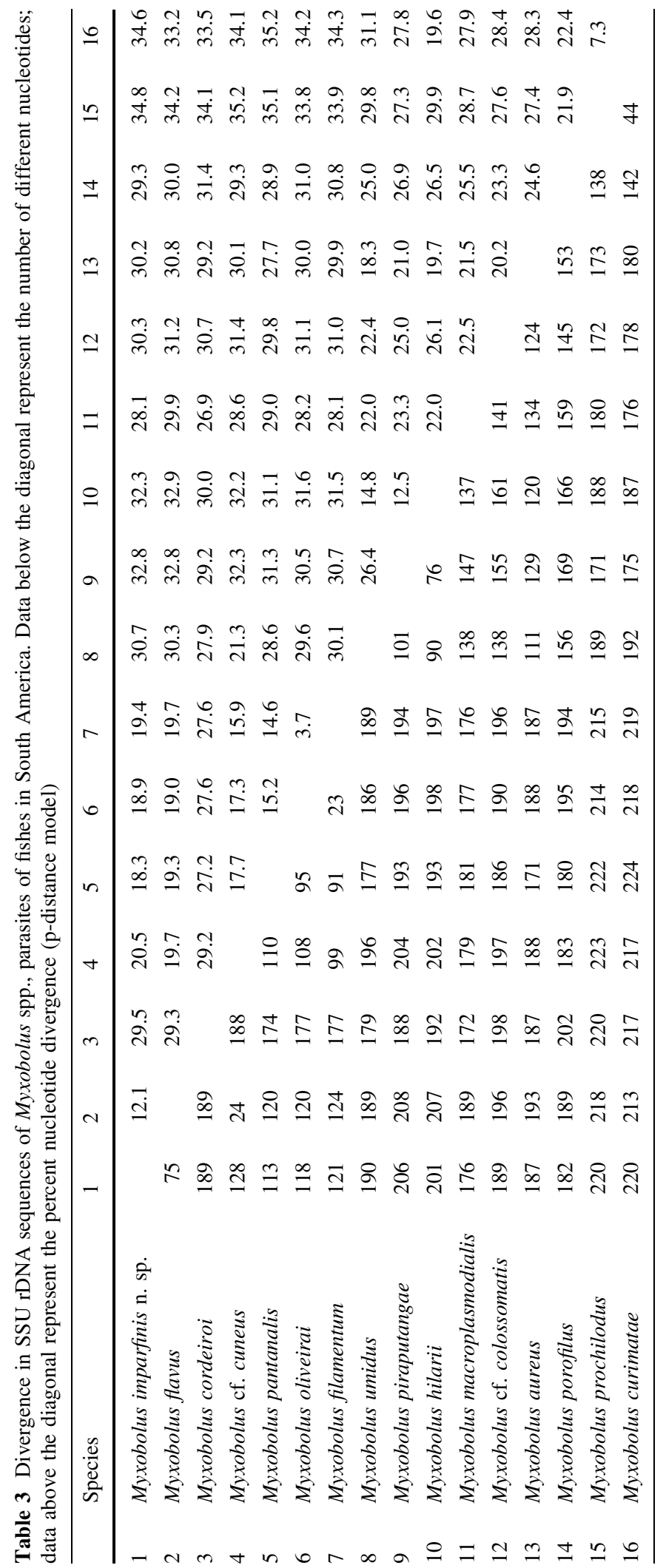




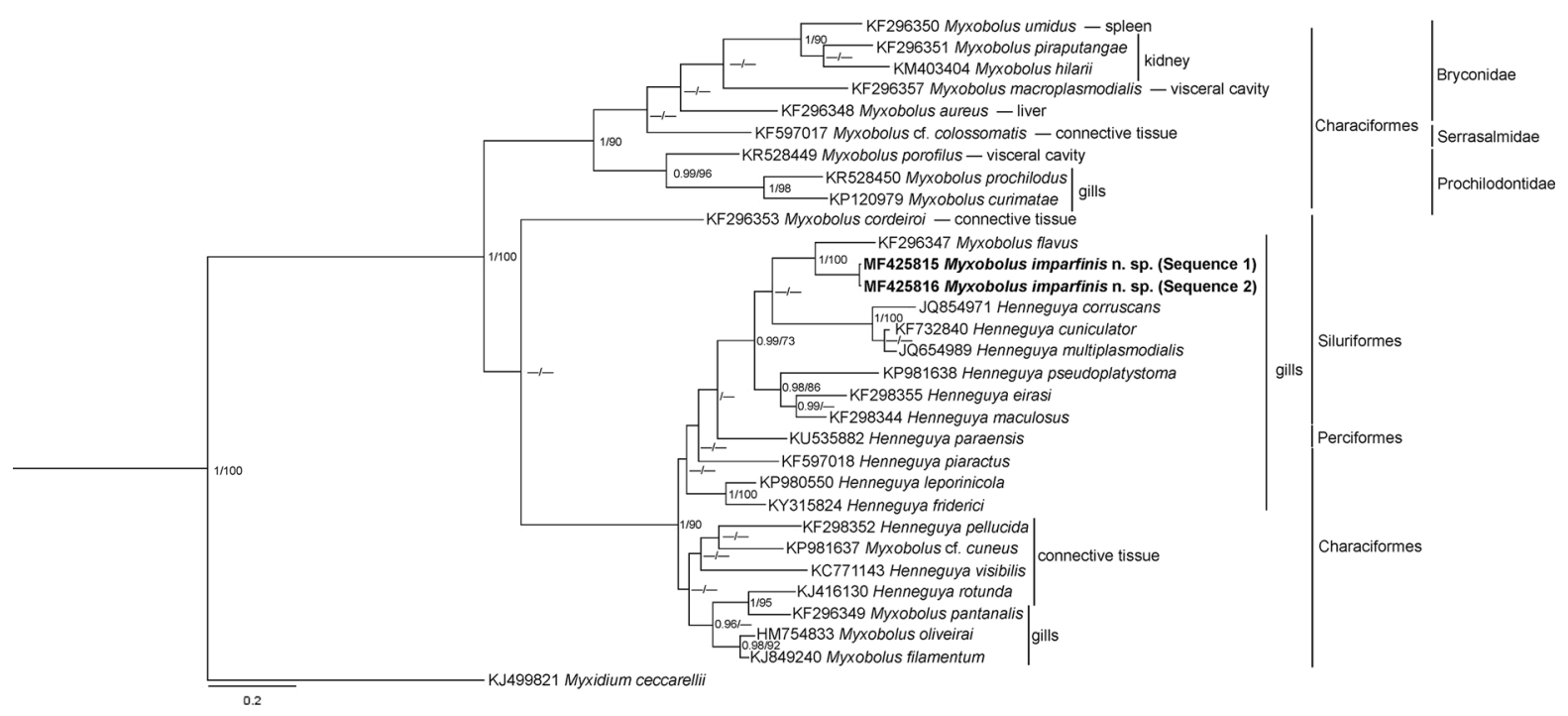

Fig. 5 Maximum likelihood (ML) phylogenetic tree based on partial SSU rDNA sequences showing the position of Myxobolus imparfinis n. sp. among other species of Myxobolus/Henneguya from South America. Numbers at the nodes represent Bayesian posterior probability (BI) and ML bootstrap values (BI/ML); only values $>0.95$ (BI) and 70\% (ML) are shown. The scale-bar indicates the distances in substitutions per site

\section{Discussion}

Recent studies have shown that myxozoan parasites tend to cluster by tissue tropism in the host (Andree et al., 1999). Myxobolus imparfinis n. sp. was resolved as the sister species of the gill parasite M. flavus within the clade containing representatives of the two genera. The sequences of the two species showed a difference of $12.1 \%$ (75 nt). The interspecific divergence within Myxobolus ranged between $0.1 \%-3.0 \%$ thus supporting the distinct status of the new species (Andree et al., 1999). Henneguya spp. that parasitise gills of siluriform fishes, such as Henneguya corruscans Eiras, Takemoto \& Pavanelli, 2009 from the gills of Pseudoplatystoma corruscans (Spix \& Agassiz), Henneguya cuniculator Naldoni, Maia, da Silva \& Adriano, 2014 from the gills of P. corruscans and Henneguya multiplasmodialis Adriano, Carriero, Maia, Silva, Naldoni, Ceccareli \& Arana, 2012 from the gills of $P$. corruscans and Pseudoplatystoma reticulatum (Eigenmann \& Eigenmann), also clustered in this clade.

Mainly due to the artificiality of morphometric characters, Myxozoa are known to include several paraphyletic and polyphyletic taxa (Fiala, 2006). The clustering of myxozoans in clades by host order and host family observed shows a tendency that parasites of the genus Myxobolus and Henneguya had a polyphyletic origin with the host specificity influencing parasitism (Capodifoglio et al., 2016).

The histological analysis of the gills of I. mirini infected with spores of $M$. imparfinis $\mathrm{n}$. sp. following the terminology proposed by Molnár (2002), we were able to classify the infection being of the filamental type and vascular subtype. According to Molnár (2002), this type is one of the most common plasmodium development, although we did not observe the formation of plasmodia. Adriano et al. (2005) showed that massive myxozoan infections could compromise gill functions by deforming the lamellar structures and reducing the gill area. However, in the present study it was not possible to observe any apparent damage to the host caused by $M$. imparfinis $\mathrm{n}$. sp.

The differences in spore morphology and morphometry and SSU rDNA gene sequences obtained in the present study tend to justify the distinct status of the new species. This contributes to the knowledge of the biodiversity of myxozoans in Brazil and of myxozoans in rarely parasitised fish gill tissues, such as the afferent branchial artery. To the best of our knowledge, $M$. imparfinis $\mathrm{n}$. sp. is the first myxozoan species described and the first record of a myxozoan 
species parasitising species of the genus Imparfinis and I. mirini.

Acknowledgements We would like to thank Reinaldo José da Silva for your support during this research.

Funding We are grateful to Fundação de Amparo à Pesquisa do Estado de São Paulo (FAPESP) (Process: 2014/12862-0 and 2015/24901-2).

\section{Compliance with ethical standards}

Conflict of interest The authors declare that they have no conflict of interest.

Ethical approval All applicable institutional, national and international guidelines for the care and use of animals were followed.

\section{References}

Adriano, E. A., Arana, S., Alves, A. L., Silva, M. R. M. D., Ceccarelli, P. S., Henrique-Silva, F., \& Maia, A. A. M. (2009). Myxobolus cordeiroi n. sp., a parasite of Zungaro jahu (Siluriformes: Pimelodiade) from Brazilian Pantanal: morphology, phylogeny and histopathology. Veterinary Parasitology, 162, 221-229.

Adriano, E. A., Arana, S., \& Cordeiro, N. S. (2005). Histophatology and ultrastructure of Henneguya caudalongula sp. n. infecting Prochilodus lineatus (Pisces: Prochilodontidae) cultivated in the state of São Paulo, Brazil. Memórias do Instituto Oswaldo Cruz, 100, 177-181.

Andree, K. B., Gresoviac, S. J., \& Hedrick, R. P. (1997). Small subunit ribosomal RNA sequences unite alternate actinosporean and myxosporean stages of Myxobolus cerebralis the causative agent of whirling disease in salmonid fish. Journal of Eukaryotic Microbiology, 44, 208-215.

Andree, K. B., Székely, C., Molnár, K., Gresoviac, S. J., \& Hedrick, R. P. (1999). Relationships among members of the genus Myxobolus (Myxozoa: Bilvalvidae) based on small subunit ribosomal DNA sequences. Journal of Parasitology, 85, 68-74.

Azevedo, C., Casal, G., Marques, D., Silva, E., \& Matos, E. (2011). Ultrastructure of Myxobolus brycon $\mathrm{n}$. sp. (Phylum Myxozoa), parasite of the Piraputanga fish Brycon hilarii (Teleostei) from Pantanal (Brazil). Journal of Eukaryotic Microbiology, 58, 88-93.

Azevedo, C., Casal, G., Mendonça, I., Carvalho, E., Matos, P., \& Matos, E. (2010). Light and electron microscopy of Myxobolus sciades n. sp. (Myxozoa), a parasite of the gills of the Brazilian fish Sciades herzbergii (Block, 1794) (Teleostei: Ariidae). Memórias do Instituto Oswaldo Cruz, 105, 203-207.

Barassa, B., Adriano, E. A., Arana, S., \& Cordeiro, N. S. (2003). Henneguya curvata sp. n. (Myxosporea: Myxobolidae) parasitizing the gills of Serrasalmus spilopleura (Characidae: Serrasalmidae), a South American freshwater fish. Folia Parasitologica, 50, 151-153.
Barta, J. R., Martin, D. S., Liberator, P. A., Dashkevicz, M., Anderson, J. W., Feigner, S. D., et al. (1997). Phylogenetic relationships among eight Eimeria species infecting domestic fowl inferred using complete small subunit ribosomal DNA sequences. Journal of Parasitology, 83, 262-271.

Buckup, P. A., Menezes, N. A., \& Ghazzi, M. S. (2007). Catálogo das espécies de peixes de água doce do Brasil. Rio de Janeiro: Museu Nacional, Universidade Federal do Rio de Janeiro.

Capodifoglio, K. R., Adriano, E. A., Milanin, T., Silva, M. R., \& Maia, A. A. (2016). Morphological, ultrastructural and phylogenetic analyses of Myxobolus hilarii n. sp. (Myxozoa, Myxosporea), a renal parasite of farmed Brycon hilarii in Brazil. Parasitology International, 65, 184-190.

Carriero, M. M., Adriano, E. A., Silva, M. R., Ceccarelli, P. S., \& Maia, A. A. (2013). Molecular phylogeny of the Myxobolus and Henneguya genera with several new South American species. PLoS One, 8, e73713.

Cellere, E. F., Cordeiro, N. S., \& Adriano, E. A. (2002). Myxobolus absonus sp. n. (Myxozoa: Myxosporea) parasitizing Pimelodus maculatus (Siluriformes: Pimelodidae), a South American freshwater fish. Memórias do Instituto Oswaldo Cruz, 97, 79-80.

Eiras, J. C., Zhang, J. Y., \& Molnár, K. (2014). Synopsis of the species of Myxobolus butschli, 1882 (Myxozoa: Myxosporea: Myxobolidae) described between 2005 and 2014. Systematic Parasitology, 88, 11-36.

Ferraris, C. J. (2007). Checklist of catfishes, recent and fossil (Osteichthyes: Siluriformes), and catalogue of siluriformes primary types. Zootaxa, 1418, 180-356.

Fiala, I. (2006). The phylogeny of myxosporea (myxozoa) based on small subunit ribosomal RNA gene analysis. International Journal for Parasitology, 36, 1521-1534.

ICZN (2012). International Commission on Zoological Nomenclature: Amendment of articles 8, 9, 10, 21 and 78 of the International Code of Zoological Nomenclature to expand and refine methods of publication. Bulletin of Zoological Nomenclature, 69, 161-169.

Kearse, M., Moir, R., Wilson, A., Stones-Havas, S., Cheung, M., Sturrock, S., et al. (2012). Geneious Basic: an integrated and extendable desktop software platform for the organization and analysis of sequence data. Bioinformatics, 28, 1647-1649.

Larkin, M. A., Blackshields, G., Brown, N. P., Chenna, R., McGettigan, P. A., McWilliam, H., et al. (2007). Clustal W and Clustal X version 2.0. Bioinformatics, 23, 2947-2948.

Lom, J., \& Arthur, J. R. (1989). A guideline for the preparation of species descriptions in Myxosporea. Journal of Fish Diseases, 12, 151-156.

Lom, J., \& Dyková, I. (2006). Myxozoa genera: Definition and notes on taxonomy, life cycle terminology and pathogenic species. Folia Parasitologica, 53, 1-36.

Mathews, P. D., Maia, A. A., \& Adriano, E. A. (2016). Morphological and ultrastructural aspects of Myxobolus niger n. sp. (Myxozoa) gill parasite of Corydoras melini (Siluriformes: Callichthyidae) from Brazilian Amazon. Acta Tropica, 158, 214-219.

Molnár, K. (2002). Site preference of fish myxosporeans in the gill. Diseases of Aquatic Organisms, 48, 197-207.

Posada, D. (2008). jModelTest: phylogenetic model averaging. Molecular Biology and Evolution, 25, 1253-1256. 
Rambaut, A. (2012). FigTree v1.4. Molecular evolution, phylogenetics and epidemiology. http://tree.bio.ed.ac.uk/ software/figtree/05/2017. Accessed 24 April 2017.

Ronquist, F., \& Huelsenbeck, J. P. (2003). MrBayes 3: Bayesian phylogenetic inference under mixed models. Bioinformatics, 19, 1572-1574.
Székely, C., Shaharom-Harrison, F., Cech, G., Mohamed, K., \& Molnár, K. (2009). Myxozoan pathogens of Malaysian fishes cultured in ponds and net-cages. Diseases of Aquatic Organisms, 83, 49-57. 